\title{
PERFORMANCE ANALYSIS OF MASONRY BUILDING WITH COURTYARD
}

\author{
R. Shrestha ${ }^{1}$, R. S. Prajapati ${ }^{2}$ \\ ${ }^{1,2}$ Department of Civil Engineering, Khwopa College of Engineering, Libali-2, Bhaktapur.
}

\begin{abstract}
A courtyard masonry building is a series of masonry buildings built in-close forming a square or rectangular space at middle of buildings. Courtyard is the central part of the buildings. It is also the flourishing place for social and cultural activities and the safer place for rescue and shelter during earthquake. In different places of Kathmandu valley courtyard typed housing is found which are historically important and preserved as a world heritage sites. These buildings are susceptible to damage due to interaction of adjacent building and due to the arrangement of buildings in courtyard pattern. This study evaluates the performance of the buildings in court-yard form during seismic loading. Typical arrangement and height of the buildings in conglomeration which is usually found in different parts of Bhaktapur district are selected. From the simulation and analysis, the buildings in conglomeration are more flexible and resist more seismic force, while the buildings in corner are more vulnerable, and hence weak for the same seismic loading.
\end{abstract}

Keywords: Courtyard, conglomeration, masonry, buildings, seismic force, response

\section{Introduction}

Courtyard housing is the system of construction of houses providing a common open space at the center of surrounding houses. Courtyard housing has existed for thousands of years from the Neolithic settlement. Courtyard housing serves security, secrecy and enclosed opening for different day to day task like space for drying, washing, social gathering, preparing utensils, drying serials etc. According to Bandyopadhyay (2014), even after the end of Indus Valley Civilization around 900 B.C, courtyard dwelling has continued in the Indian subcontinent to the present day. The history of the courtyard system is very ancient; however, the system has great importance as before for passive design strategies. The size of courtyard varies with the purpose and type of the community in Kathmandu valley. There are different types of courtyard system in Kathmandu valley like, very large space for drying rice and serials, making and burning ceramic utensils.

\footnotetext{
*Corresponding author: R. Shrestha

Department of Civil Engineering, Khwopa College of

Engineering, Libali-2, Bhaktapur, Nepal

Email: rshrestha@yahoo.com

(Received: 2015 June 12 Accepted: 2015 Aug 18)
}

Nanies to dye clothes; Bahas and Bahis perform different cultural ceremonies. These buildings are built very close to each other or in the way they are joined together. Past earthquakes have demonstrated that the buildings in the historic city are susceptible to damage.

Rana (1936), mentioned that houses properly connected with each other by interlocking the bricks and wooden beams suffered less damage. Proper connection makes no hammering effect between adjacent walls of the buildings during the earthquake.

Out-of-plane bending of walls is a common local failure mechanism in poorly constructed buildings with weak connections between walls and floors with poor masonry materials. This study attempts to determine some simple relationships of buildings within conglomeration in courtyard in order to describe the interaction effects on the series during an earthquake. The purpose of this study is to determine the role that building interaction should play in evaluating the seismic vulnerability of historic city centers. 


\subsection{Structural Detail and Assign Loads}

All the buildings selected for this study are about 35-40 years of age. They are brick masonry with mud mortar. The floor levels and heights of the buildings are different as compared each other. Large openings in the building put these buildings in danger. It is observed that all buildings have similar large openings, doors and windows. The spindle beams in the buildings are less. Even though the buildings are situated in the core of the Bhaktapur city, there are no any remedial measures undertaken to strengthen building to resist seismic load and the vulnerability condition of the buildings are not studied too.

For this study, properties of construction materials taken from FEMA 356-200 as summarized in Table 1 were used for the modelling of the buildings. The specific weight of masonry work was taken as $19 \mathrm{kN} / \mathrm{mm}^{2}$ and frictional coefficient as 0.5 from FEMA 3562000.

Table 1 Material properties adopted in modelling of buildings

\begin{tabular}{|l|c|}
\hline \multicolumn{1}{|c|}{ Description } & $\begin{array}{c}\text { Allowable Stress } \\
\left(\mathrm{N} / \mathrm{mm}^{2}\right)\end{array}$ \\
\hline Elastic modulus & 1500 \\
\hline Shear modulus & 250 \\
\hline Compressive stress & 2.4 \\
\hline $\begin{array}{l}\text { Design shear strength } \\
\text { without vertical stress }\end{array}$ & 0.2 \\
\hline
\end{tabular}

There are no proper connections between the buildings. Buildings are built side by side without any spacing. The location plan is shown in the google image (Fig 1). A sketch of the building arrangement is shown in fig 2 which is used in study.

Gravity loads on the structure include the selfweight of the walls and slabs. Live loads have been assigned as uniform area loads on the slab elements. Live load on roof is $1 \mathrm{kN} / \mathrm{m}^{2}$ and live load on all other floors is $2 \mathrm{kN} / \mathrm{m}^{2}$. Percentage of Imposed load considered in seismic weight calculation is $25 \%$ of the imposed load. As per
IS 1893 (Part 1) 2002, for live load class up to 3 $\mathrm{kN} / \mathrm{m}^{2}, 25 \%$ of the imposed load have been considered.

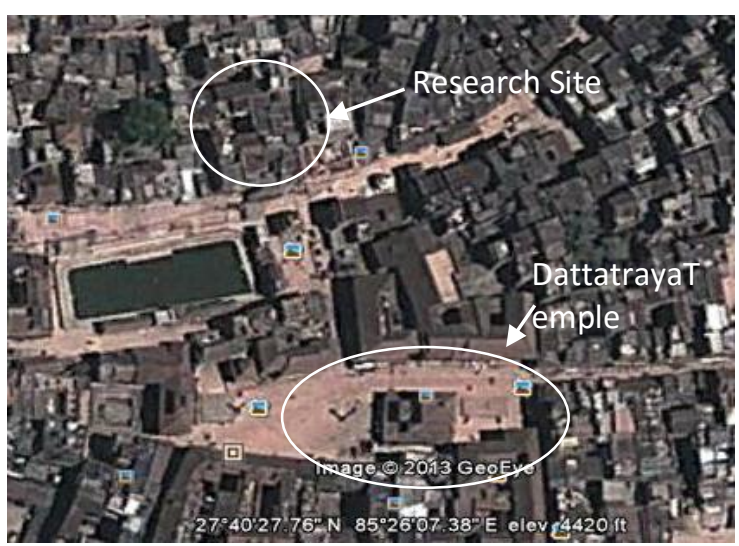

Fig 1 Location plan of research site.

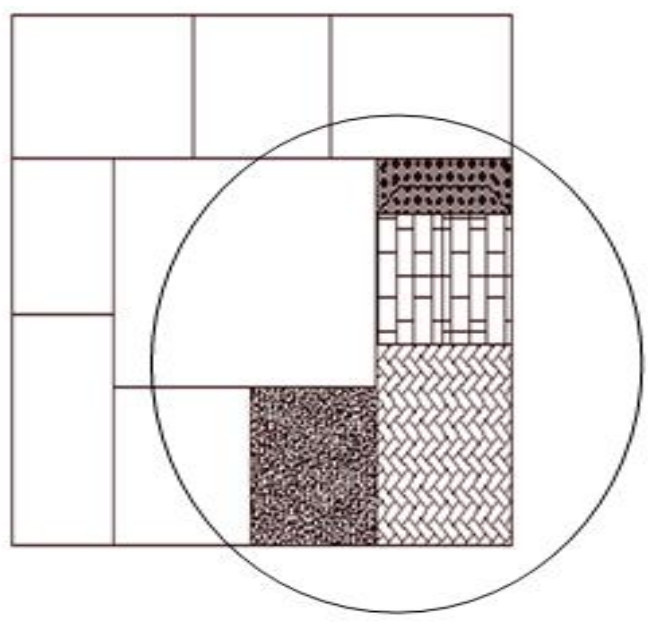

Fig 2 Sketch of the selected buildings.

\subsection{Modelling and Analysis of Structure}

A series of buildings are considered in order to compare various parameters of building. The goal is to draw global behavior of the buildings. According to Laefe (2011), the micro model generated marginally better results than the macro but required approximately ten times the resources. The resources were physical test which includes horizontal and vertical displacement of buildings, computational costs including CPU time, storage, competence, human cost, and computer hardware. The 
comparison shows that the macro model can provide a general response of building subjected to ground movement.

According to Shakya M (2014), the main difficulties in numeric modelling of historic buildings and, particularly, for temple structures are

- Lack of data on geometric dimensions;

- Difficulties in identifying the characteristics of construction materials;

- Excessive cost of detailed laboratory testing;

- Variability of the data due to construction techniques and workmanship quality;

- Heterogeneous material properties for the same structural member due to traditional long term construction process.

In this study numerical modelling of the masonry building is done which have typical properties of clay brick masonry and good quality masonry unit. Similar property of masonry is used in every building for modelling. The dimensions used in the modelling of the buildings were summarized in Table 2.

Similarly, the walls are assumed to be thick enough and sufficiently attached to the floor to ensure out-of-plane stability and structural redundancy. The roofs are flat, so no additional horizontal thrusts are present. Three different parameters are considered in the analysis of effect of building interaction.

Table 2 Dimension adopted in modelling of building

\begin{tabular}{|l|c|}
\hline \multicolumn{1}{|c|}{ Description } & Dimension $(\mathrm{mm})$ \\
\hline Wall thickness & 500 \\
\hline Thickness of slab & 150 \\
\hline $\begin{array}{l}\text { Maximum } \\
\text { unsupported length }\end{array}$ & 1600 \\
\hline Floor height & Vary from 1580 - 1680 \\
\hline
\end{tabular}

These parameters are:

- Height of the building

- Mass of the building

- Position within conglomeration
These parameters are directly correlated with the building interaction. The length of the buildings is different. The internal wall configuration was not considered. The walls which are of different width can create flexible and rigid building systems. The short width walls tend to be more flexible and are governed by a rocking mechanism while the long width walls tend to be more rigid and are governed by a shear sliding mechanism. According to the width and height of the wall the stiffness of gap element is modeled with the equation given in FEMA 356 (equation C7-1). The gap element is used in the junction of two adjacent building. The heights of stories for each building also vary. Change in the height of the buildings changes the base shear, the stiffness and the natural period of the building, all of which are important characteristics in determining building response. The material for the floors is modeled as rigid diaphragm. The structure was modeled using SAP2000.

Time history analysis has been carried out to determine the various structural parameters of the model. Structures are mainly concerned with the effect of ground motion and dynamic excitations such as earthquakes and the displacement of the structure in the elastic range. Buildings of different size were taken in conglomeration. They were modeled as individual (single) as well as combined. The separate analysis was done to compare the performance of the single and combined building in different earthquake time history. In this study, time history analysis was done using SAP2000 (Computers and Structures) software.

Time History function analysis has been carried out using earthquake time history function of Elcentro earthquake, Chamoli earthquake and Lalitpura earthquake, shown in fig 4, fig 5 and fig 6 respectively. These time history functions are simulated in the arrangement of building shown in Fig 3. 


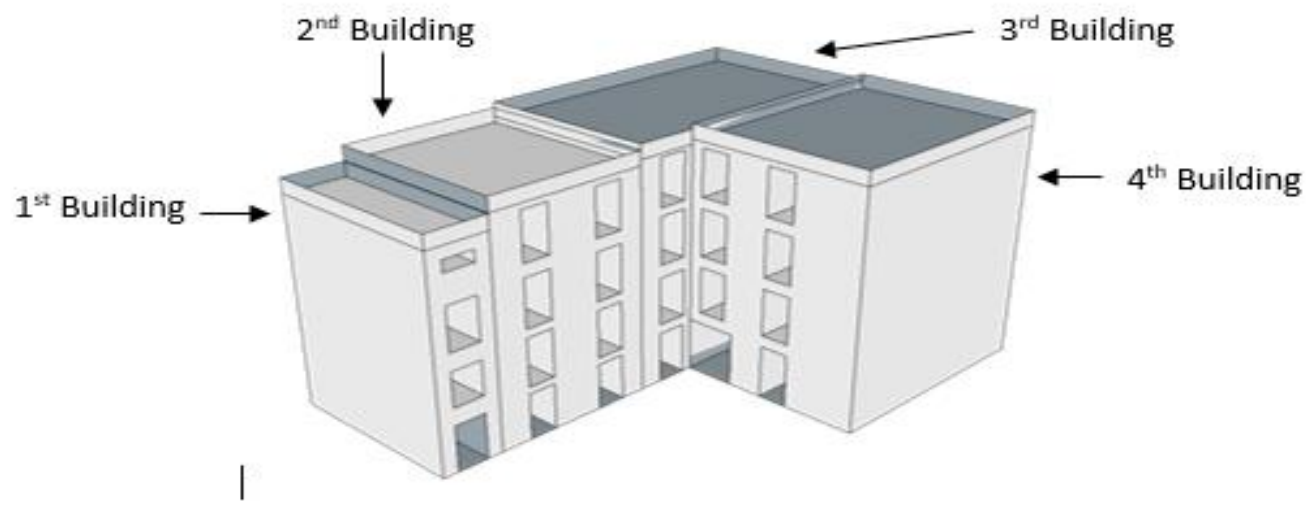

Fig 3 3D view of the buildings.

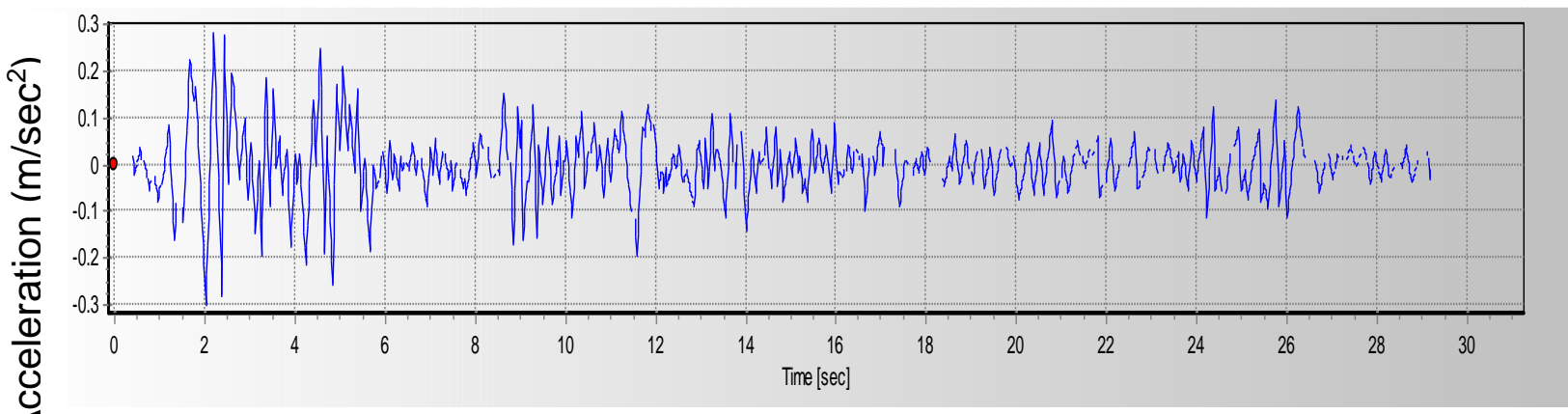

Fig 4 Elcentro earthquake time history graph.

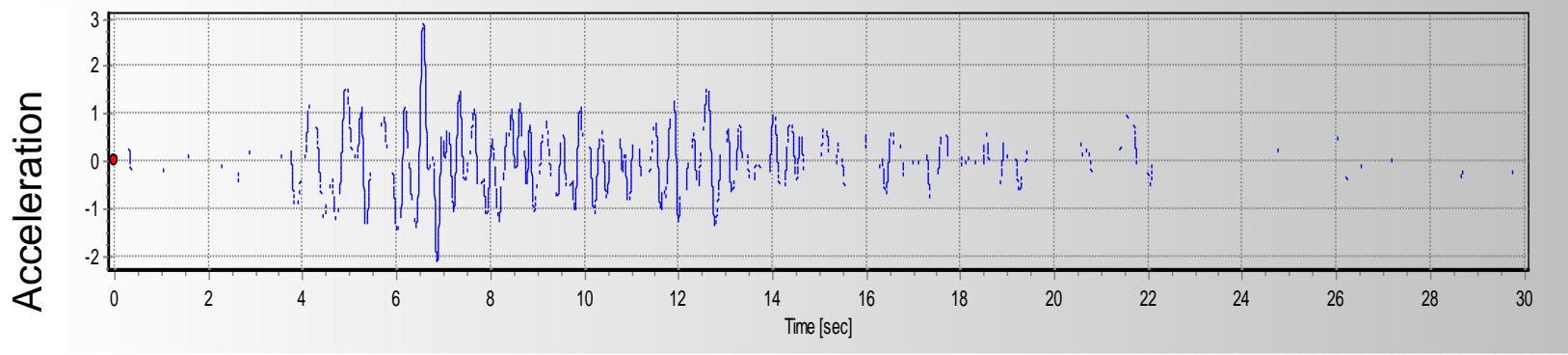

Fig 5 Chamoli earthquake time history graph.

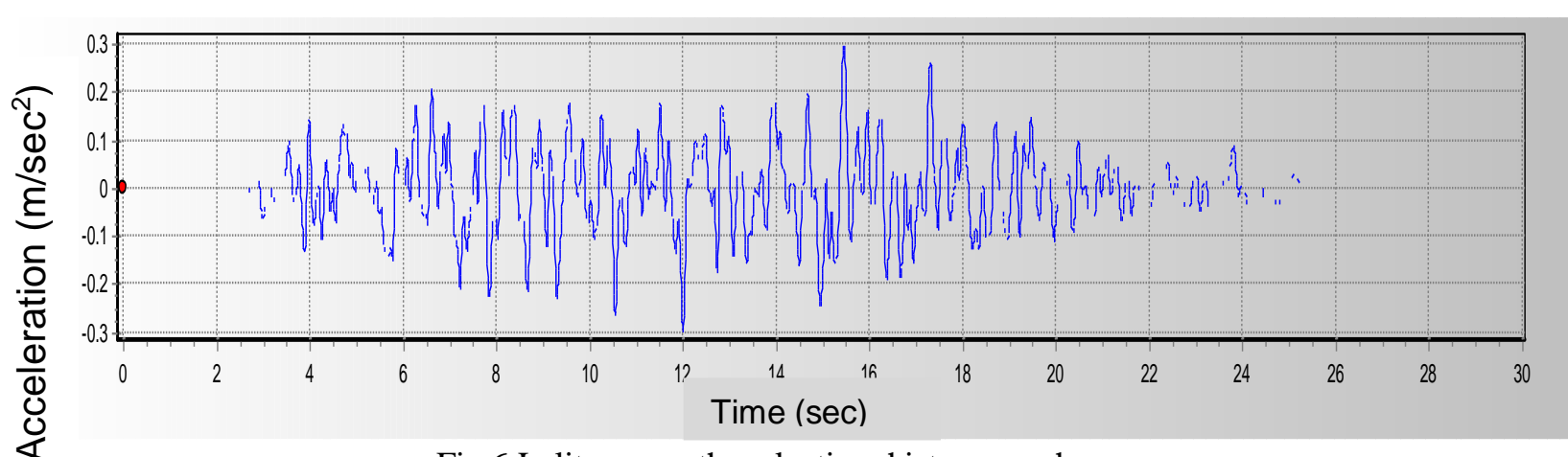

Fig 6 Lalitpura earthquake time history graph. 


\subsection{Results}

\subsection{Mode and Natural Period of Vibration}

In time history analysis or in the dynamic analysis of the building first mode of vibration is the major time period of vibration. In general building in first mode vibration is more critical than other mode. However, sometimes in other mode also the buildings are highly deflected. In this system the buildings are in conglomeration forming L-shape. The buildings are just constructed side by side and there is no any interconnection system between the adjoining buildings. While comparing the graphs of the single/individual modeled building versus combined modeled building, the combined modeled building's first natural period of vibration is less in all four single modeled buildings (fig 7). The combined modeled building first mode and second mode of vibration shows it resonates at a low frequency. But in third mode and fourth mode of vibration, the natural period of vibration is higher than single modeled building. It represents that the combine modeled building responses like a flexible building compared to the single modeled building (Fig 3). From the results it can be concluded that the buildings in conglomeration reinforce each other and helps to resist the earthquake damage.

\subsection{Inter Story Drift}

The inter story drift percent from Chamoli time history and Lalitpura time history shows that the effect of these two function is more than the Elcentro time history for this first building (Fig 8) . Amplification is about double in individual form. Also in case of second building, the input acceleration shows prior effect in individual case than in the combined case (Fig 9). The Chamoli time history and Lalitpura time history amplify the drift ratio about $45 \%$ more in individual form, where the El-centro time history function only resonant the drift ratio about $20 \%$ more than the combined form. But in case of third modeled building the amplification is more than $60 \%$ in combined form than the single form (Fig 10). The third building is in the corner of the conglomeration. Corner part of any building is very vulnerable in dynamic loading. The building constructed in corner of conglomeration is more likely to collapse on dynamic loading than other adjacent building. The corner building shall be constructed more strong than the same building constructed in separate form. Other buildings in conglomeration get strength due to the arrangement than the same building in separate form. The capacity of the building is compared with the table of the code FEMA-356-2000 (Table C1-3).

\subsection{Time History Function and Ground Acceleration}

Buildings in El-centro, Chamolia and Lalitpura time history function respond differently in individual and combine form. For the analysis of acceleration of building one top point of each of building is considered.

For different time history function analysis, the first, second and forth building gets more accelerated in individual form than in the combined form. Conversely, the third building accelerated more in combined form than in the single form. For El-centro ground acceleration individual case building gets accelerated almost in $5 \mathrm{sec}, 10 \mathrm{sec}, 15 \mathrm{sec}$ and $25 \mathrm{sec}$ higher than that in the combined case.

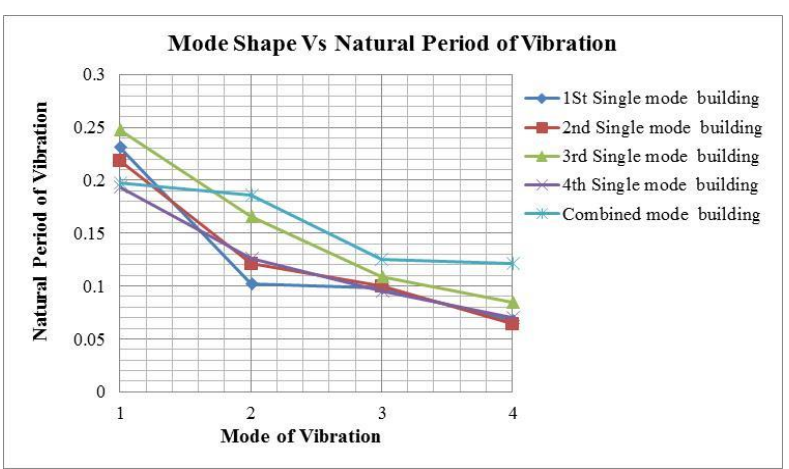

Fig 7 Mode shape Vs time period of vibration.

(Note: - Solid line for individual form/modeled building and broken line for combined form/modeled building) 


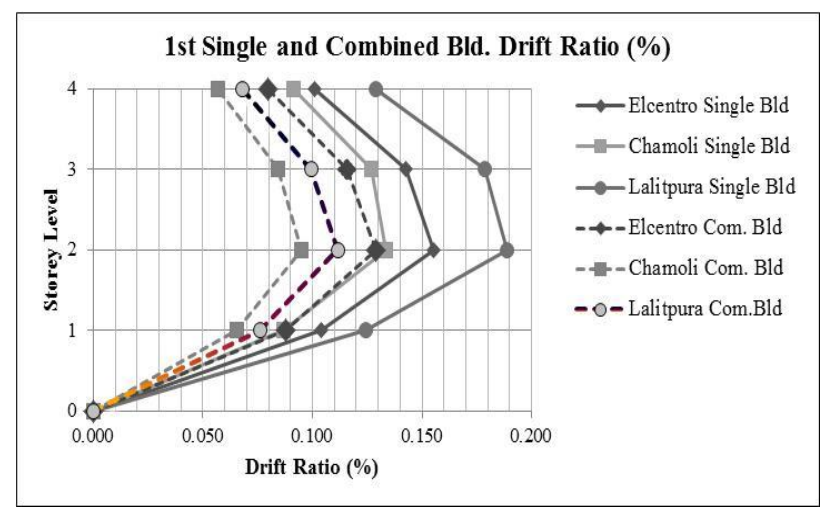

Fig $81^{\text {st }}$ Single and combined building drift ratio graph.

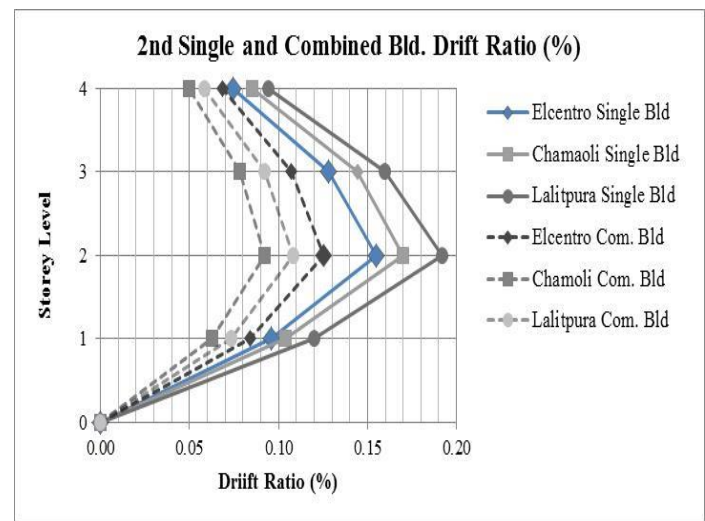

Fig $92^{\text {nd }}$ Single and combined building drift ratio graph.

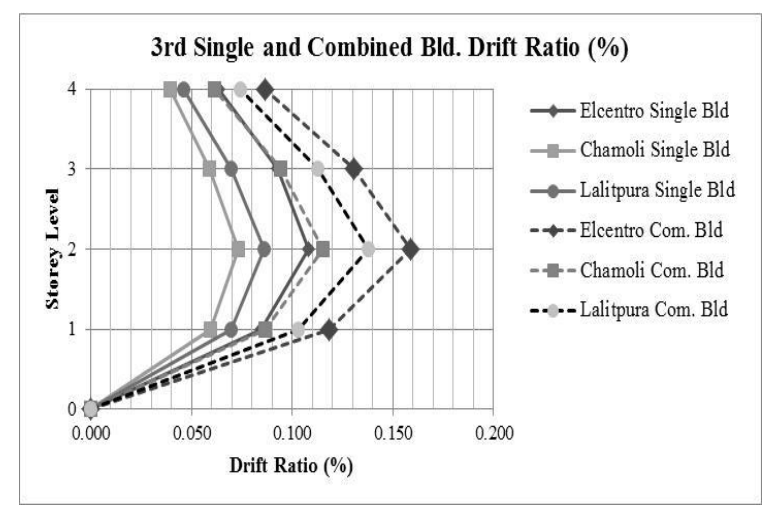

Fig $103^{\text {rd }}$ Single and combined building drift ratio graph.

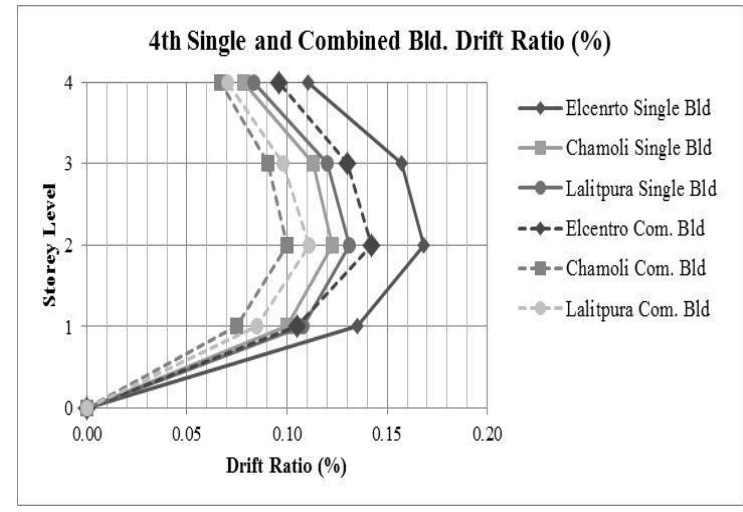

Fig $114^{\text {th }}$ Single and combined building drift ratio graph.

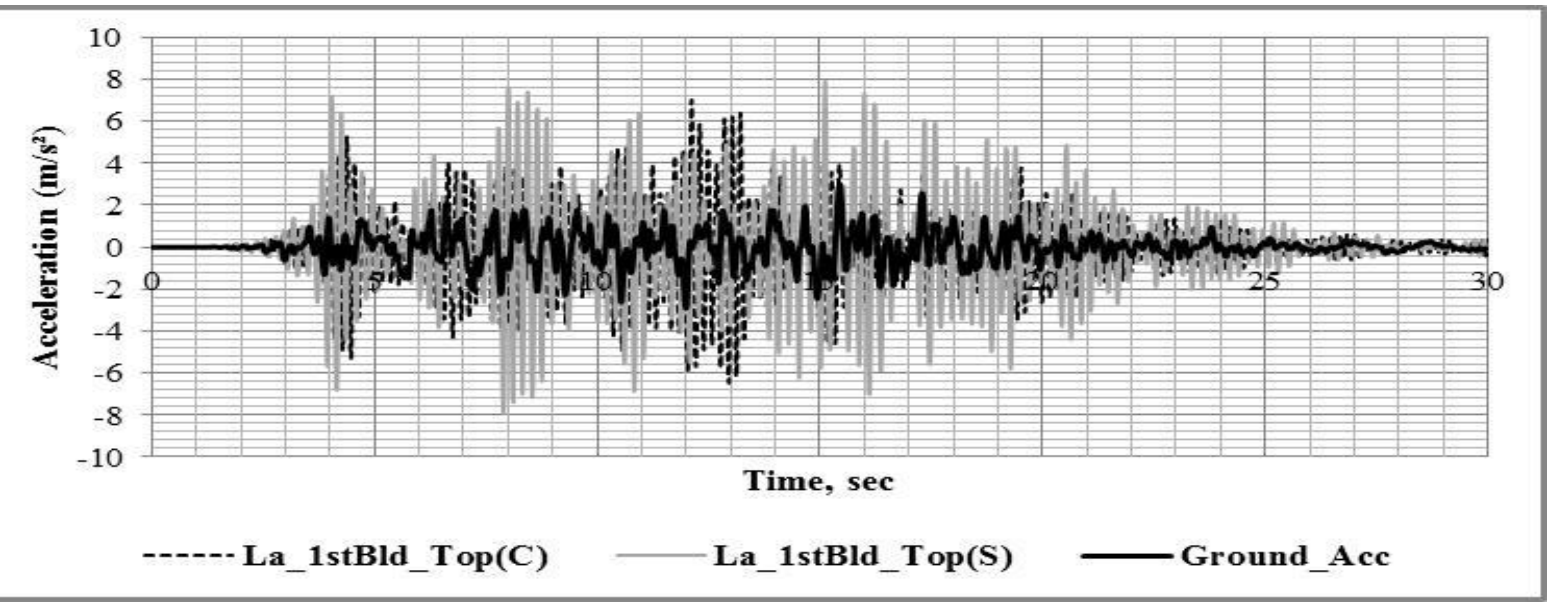

Fig 12 Time history graph of Lalitpura earthquake at $0.3 \mathrm{~g}$ for $1 \mathrm{st}$ building. 


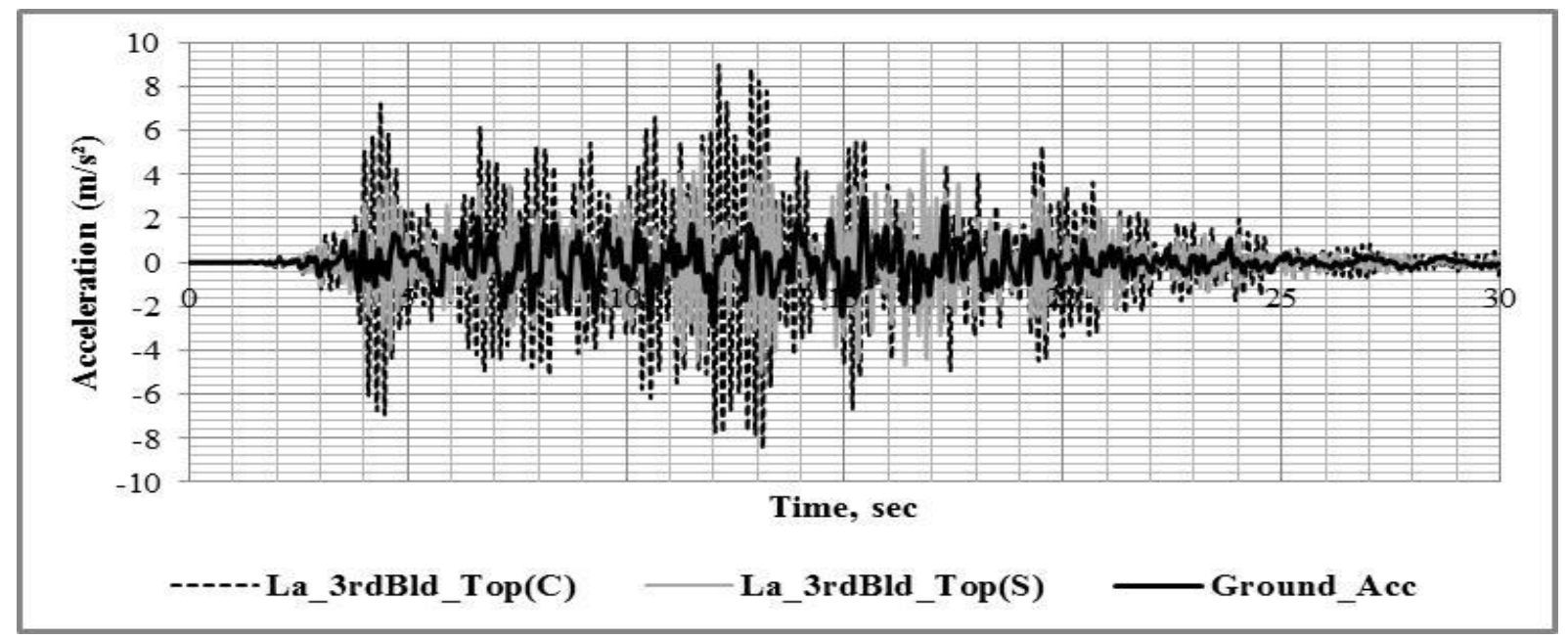

Fig 13 Time history graph of Lalitpura earthquake at $0.3 \mathrm{~g}$ for $3^{\text {rd }}$ building.

Similarly, in case of Lalitpura the individual case building gets highly accelerated almost all the time. The third building which is at the corner of the conglomeration shows different response in the given time history acceleration. This building response in all the time history is greater in combined form than in the individual case. Combined case gets highly accelerated almost all the time in all three time history input. The forth building is peculiar too. It is the second largest building in our conglomeration. Amplification is not significant, and there is almost similar amplification in individual and combined case. The individual building accelerates more with respect to combined building.

(Note: - Dark solid line for actual ground acceleration in $0.3 \mathrm{~g}$, feint continuous line for individual form/modeled building and broken line for combined form/modeled building)

\subsection{Discussions}

The natural period of vibration shows that the building in conglomeration time period is the average of the buildings, which is very near to the two large buildings and also is at the corner of the conglomeration. From the combined and single modeling, it is found that the time period of vibration of the combined mode is more. It shows that the building gets flexibility and strength in conglomeration. The drift ratio of buildings in individual form is remarkable greater about 50\% than the building in conglomeration. This also proves that there is great advantage to build buildings in conglomeration if the local effects can be reduced by adopting proper connection, same floor level and similar height of building. However there is also some of the disadvantage in building houses in courtyard form. The corner of the house is more susceptible to get damaged during earthquake than other houses. As in an individual form building, the corner part is damaged in earthquake due to the load concentration, less support and out of plane behavior. Same theory is also applicable in the courtyard typed masonry building.

According toWang (2011), in the cases of courtyard house with continuous rigid walls, it is observed that the joints between the main house and the side houses have a tendency to break. In a minor damage situation, the gable wall at the end of the side house may be tilted by the two walls perpendicular to it. In serious failure cases, the whole structure of the corner rooms collapses.

Time history curves of all the three buildings, $1^{\text {st }}$, $2^{\text {nd }}$ and $4^{\text {th }}$, show that the spectral acceleration of the individual form of building is twice the combined form building. In case of the $3^{\text {rd }}$ building, the combined form building spectral acceleration is one 
and half as much as than the individual form. This also justifies that the corner building should be strongly constructed. The historical data also shows that the corner buildings are damaged in earthquake. From one of the pictures published in the historical book Nepal- Behar Earthquake, by Rana (1936), the corner of courtyard building had collapsed due to earthquake (Fig 14).

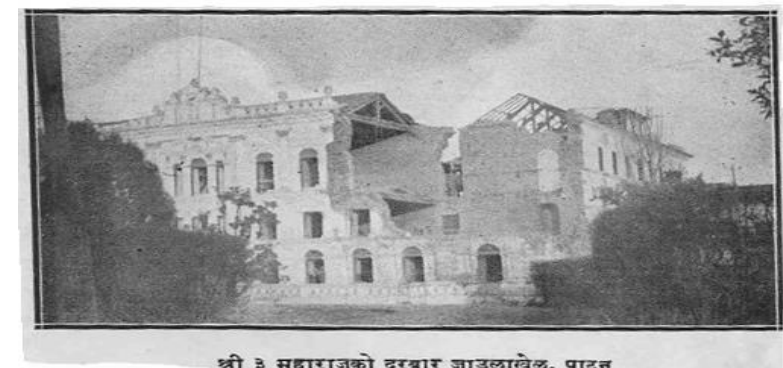

Fig 14. Jaulakhel Darvar after 1990 BS earthquake.

\subsection{Conclusion}

In this study, three different seismic time history functions were used to analyze four different building in individual form and in combined form. In the analysis, four factors have been considered such as, buildings height, wall length, floor type and position within conglomeration. The buildings in conglomeration have remarkable capacity to withstand earthquake force than in separate situation. Buildings in conglomeration are more flexible and support each other. However there is also a limitation in the system as the building at the corner is more vulnerable and has more probability of collapsing. The buildings show different response in different seismic time history function. Hence from the results it can be concluded that the mass of the building, position in conglomeration and the ground acceleration affect the response of building. Likewise, it can be concluded that the corner of the building are more vulnerable in courtyard compared to other buildings, they need to be constructed with more care and strength.

Acknowledgment:The authors would like to acknowledge the support provided by Khwopa College of Engineering and Khwopa Engineering College. They would also like to extend appreciation to the reviewers for their valuable positive suggestion.

\section{References}

[1] Bandyopadhyay, S. S. (2014). Courtyard houses: An overview. Recent Research in Science and Technology, 4.

[2] Chopra, A. (1996). Dynamics of Structure, Theory and Application to Earthquake Engineering. Eastern Economic Edition, Prentice Hall of India.

D’Ayala D., S. R. (1996). Vulnerability of buildings in historic town centers: a limit-state approach. Proceedings of XI World Conference on Earthquake Engineering, Mexico.

FEMA 356 [2000] Prestandard and commentary for the seismic rehabilitation of buildings, Report No. FEMA-356, Federal Emergency Management Agency, November. (n.d.).

Finley David T., C. R. (n.d.). Equivalent Static vs. Response Spectrum A Comparison of Two Methods.

[6] IS 1893 (Part 1) : 2002 Indian Standard Criteria for Earthquake Resistant Design of Structures, Part 1 General Provisions and Buildings, (Fifth Revision). (n.d.).

[7] IS 875 (Part 2): 1987 Indian Standard Code of Practice for Design Loads (Other Than Earthquake) for Buildings and Structures, Part 2 Imposed Loads. (Second Revision). (n.d.).

[8] Kramer, S. (1996). Geotechnical Earthquake Engineering. Pearson Educational Inc.

[9] Laefer, L. T. (2008-11). Micro Vs. Macro Models for Predicting Building Damage Underground Movements. 10.

[10] Manjip Shakya, H. V. (2014). Seismic sensitivity analysis of the common structural. Bull Earthquake Eng, 25.

P.G., S. C. (2001). Masonry Failure Criterion Under Biaxial Stress state.

[12] PENA, F. (2004). The role of the Tension Strength in the Collapse Mechanism of Unreinforced brick Masonry Constructions. 
[13] Raheem, S. E. (2006). Seismic Pounding between Adjacent Building Structures.

[14] Rana, B. S. (1936). Nepal Behar Earthquake. Kathmandu.

[15] S.H., I. M. (2005). Performance of Masonry Building During 8th Octuber Hazard-Kashmir Earthquake in Pakisthan.
[16] Tiwari, P. S. (n.d.). Tradiational Architecture of Kathmandu Valley. Department of Architecture,IOE, 9.

[17] Wang, C.-W. C.-J. (2011). Damage to Chinese Courtyard Houses. Journal of Earthquake Engineering, 14. 